\title{
Perbedaan Manifestasi Klinis dan Laboratorium Kolestasis Intrahepatal dengan Ekstrahepatal pada Bayi
}

\author{
Dwi Prasetyo, Yudith Setiati Ermaya, Iesje Martiza \\ Departemen Ilmu Kesehatan Anak Fakultas Kedokteran, Universitas Padjadjaran \\ Rumah Sakit Dr. Hasan Sadikin Bandung
}

\begin{abstract}
Abstrak
Ikterus fisiologis sering didapatkan pada bayi dan kebanyakan gejalanya ringan. Gejala ikterik biasanya akan menghilang dalam 2 minggu setelah lahir. Pada ikterus yang terkonjugasi terjadi defek produksi intrahepatal, transpor transmembran dari empedu, yaitu kolestasis intrahepatal $(\mathrm{IH})$ atau obstruksi kolestasis ekstrahepatal (EH) yang mengakibatkan hambatan empedu. Penelitian ini dilakukan untuk melihat perbedaan manifestasi klinis dan laboratorium kolestasis IH dengan EH pada bayi. Studi potong lintang dilakukan pada 72 bayi dengan kolestasis yang datang ke Rumah Sakit Dr. Hasan Sadikin Bandung, periode Januari 2014-Desember 2015. Analisis data dilakukan dengan uji Pearson Chi-kuadrat dan Mann-Whitney. Subjek terdiri atas 43 (60\%) laki-laki dan 29 (40\%) perempuan, kolestasis IH sebanyak 61 orang (85\%), dan EH sebanyak 11 (15\%). Pada penelitian ini didapatkan perbedaan bermakna manifestasi klinis asites antara kolestasis IH dan EH $(p=0,047)$, sedangkan venektasi, hepatomegali, dan splenomegali tidak didapatkan perbedaan bermakna. Pada pemeriksaan warna feses tidak didapatkan perbedaan bermakna $(\mathrm{p}=0,936)$, demikian juga hasil laboratorium bilirubin total, bilirubin direk, glutamat oksaloasetat transaminase, glutamat piruvat transaminase, alkali fosfatase, dan gama glutamil transferase serum tidak berbeda bermakna. Simpulan, didapatkan perbedaan manifestasi klinis asites, sedangkan manifestasi klinis yang lain dan hasil laboratorium tidak didapatkan perbedaan antara kolestasis $\mathrm{IH}$ dan EH. [MKB. 2016;48(1):45-50]
\end{abstract}

Kata kunci: Kolestasis ekstrahepatal, kolestasis intrahepatal, laboratorium, manifestasi klinis

\section{Differences of Clinical Manifestation and Laboratory Findings in Intra- Hepatic and Extra-Hepatic Cholestasis in Infants}

\begin{abstract}
Physiological jaundice found in infants and most symptoms are often mild. Jaundice symptoms usually disappear within 2 weeks after birth. In conjugated jaundice defects in intra-hepatic production, transmembran transport from bile, i.e. cholestasis intra hepatic (IH), or extra-hepatic (EH) obstruction/cholestasis occur, resulting in bile barriers. This study was conducted to look at the differences in the clinical and laboratory manifestations of IH and EH cholestasis in infants. A cross-sectional study was performed on 72 infants with cholestasis who came to Dr. Hasan Sadikin General Hospital Bandung, during the period of January 2014-December 2015. Data analysis was performed with Pearson Chi-square test and Mann-Whitney. Subjects consisted of $43(60 \%)$ infant boys and 29 $(40 \%)$ infant girls, IH cholestasis were 61 (85\%) and EH cholestasis were 11 (15.3\%). Significant differences in the clinical manifestations of acites with IH and EH cholestasis were found ( $p=0.047)$, whereasinsignificant differences in venectation, hepatomegaly and splenomegaly were observed. On examination of stool color, no significant difference was found $(p=0.936)$. The same was true for laboratory results of total bilirubin, direct bilirubin, serum glutamic oxaloacetic transaminase, glutamic pyruvic transaminase, alkaline phosphatase and gamma glutamyl transferase. In conclusion, we found differences in clinical manifestation of acites, while for other clinical manifestations and laboratory results no differences were found between IH and EH cholestasis. [MKB. 2016;48(1):45-50]
\end{abstract}

Key words: Clinical manifestation, extra-hepatic cholestasis, intra-hepatic colestasis, laboratory

Korespondensi: Dr. Dwi Prasetyo, Sp.A(K), M.Kes. Departemen Ilmu Kesehatan Anak Fakultas Kedokteran Universitas Padjajaran Bandung/Rumah Sakit Hasan Sadikin Bandung, Jalan Pasteur No.38 Bandung, mobile 081221623333, e-mail dpras2016@gmail.com 


\section{Pendahuluan}

Ikterik fisiologis pada neonatus paling sering didapatkan pada bayi dan kebanyakan gejalanya ringan. Ikterik berdasarkan peningkatan kadar bilirubinnya dapat dibagi menjadi gejala ikterik yang disebabkan oleh peningkatan bilirubin tidak terkonjugasi atau fisiologis dan bilirubin terkonjugasi. Suatu gejala ikterik biasanya akan menghilang dalam 2 minggu setelah lahir, oleh karena itu sangat penting para klinisi untuk memeriksakan bayi yang masih kuning pada usia tersebut. Pada ikterus terkonjugasi gejala biasanya berat dan mengindikasikan penyebab yang mendasarinya, seperti defek produksi intrahepatal, transpor transmembran dari empedu, yaitu kolestasis intrahepatal (IH) dan obstruksi atau kolestasis ekstrahepatal (EH) yang mengakibatkan hambatan aliran empedu dan terakumulasi dalam hepar, darah atau saluran ekstrahepatal, serta mempunyai risiko tinggi untuk terjadi komplikasi pada bayi. ${ }^{1-3}$

Kolestasis adalah hambatan aliran empedu yang menyebabkan retensi berbagai substansi yang seharusnya diekskresikan dalam kandung empedu dengan bilirubin direk $>1 \mathrm{mg} / \mathrm{dL}$ bila bilirubin total $<5 \mathrm{mg} / \mathrm{dL}$ atau bilirubin direk $>20 \%$ dari bilirubin total bila kadar bilirubin total $>5 \mathrm{mg} / \mathrm{dL}^{4,5}$

Epidemiologi kolestasis pada bayi terjadi cukup tinggi, yaitu 1 per 2.500 kelahiran hidup. Penyebab paling umum kolestasis pada bulanbulan pertama kehidupan adalah atresia bilier dapat terjadi 1:10.000 hingga 1:15.000 bayi dan hepatitis neonatal. Angka kejadian lebih sering pada bayi kurang bulan dibanding dengan bayi cukup bulan., ${ }^{1,4}$ Untuk menentukan diagnosis kolestasis sering kali tidak sederhana, tetapi yang penting adalah menentukan kolestasis $\mathrm{IH}$ (hepatoseluler) atau EH (obstruktif). Prognosis memburuk apabila tidak ditangani secara dini, bahkan tidak jarang dalam penatalaksanaannya memerlukan transplantasi hati. ${ }^{6}$

Banyak cara dilakukan untuk membedakan kolestasis IH dengan EH, namun tidak ada cara yang dapat digunakan secara tunggal dengan akurasi diagnostik $100 \%$, oleh karena itu memerlukan anamnesis dan pemeriksaan fisis yang cermat dan pemeriksaan penunjang yang memadai. Obstruksi intrahepatal yang terjadi biasanya jarang seberat obstruksi ekstrahepatal sehingga kolestasis IH umumnya hanya dapat menyebabkan peningkatan alkali fosfatase yang tidak begitu tinggi dan hanya sedikit pigmen dalam feses atau urobilinogen di dalam urin apabila dibanding dengan kolestasis EH. Untuk menetapkan diagnosis yang akurat diperlukan anamnesis yang baik mengenai riwayat prenatal, perinatal, kapan mulai timbulnya gejala, riwayat keluarga, riwayat morbiditas ibu selama masa kehamilan (misalnya infeksi TORCH), riwayat kelahiran (infeksi intrapartum, berat badan lahir, usia kehamilan), morbiditas perinatal dan riwayat warna feses apakah seperti dempul atau hilang timbul (fluktuasi). ${ }^{1,7-9}$ Pemeriksaan fisis mencakup berat badan, dan tinggi badan, pemeriksaan abdomen yang mencakup lingkar perut, besarnya hati, lien, serta terdapat massa atau asites. Keadaan umum penderita kolestasis IH biasanya tampak sakit berat, sedangkan penderita kolestasis EH biasanya mempunyai keadaan umum yang baik, tetapi biasanya dapat disertai dengan kelainan kongenital lainnya. 1,7,8,10

Pemeriksaan penunjang yang dilaksanakan untuk dapat membedakan kolestasis IH dengan EH adalah pemeriksaan laboratorium terdiri atas komponen bilirubin, glutamat piruvat transaminase (SGPT), glutamat oksaloasetat transaminase (SGOT), $\gamma$-glutamil transpeptidase $(\gamma$-GT), dan alkaline phosphatase (ALP) serum. Pemeriksaan ultrasonografi (USG) abdomen 2 fase diperlukan untuk membedakan kolestasis IH (hepatitis neonatal) atau EH (obstruksi). Gambaran USG dengan triangular cord sign yang memperlihatkan massa fibrotik berbentuk kerucut atau tubular pada bagian kranial dari bifurkasio vena porta sangat membantu untuk mendiagnosis atresia biliaris. Kolangiografi intraoperatif dilakukan pada saat laparotomi eksplorasi pada kasus kemungkinan atresia biliaris. Biopsi hati merupakan cara yang paling dapat dipercaya untuk mendiagnosis bayi dengan kolestasis, namun baru dapat dilakukan sesudah bayi berusia 4 minggu. ${ }^{1,11}$ Pada penelitian ini diagnosis kolestasis IH dan EH berdasarkan USG. Tujuan penelitian ini adalah melihat perbedaan manifestasi klinis dan laboratorium kolestasis IH dengan EH pada bayi.

\section{Metode}

Penelitian ini merupakan studi potong lintang yang dilaksanakan secara retrospektif. Subjek adalah 72 bayi pasien kolestasis yang berobat ke Departemen Ilmu Kesehatan Anak Fakultas Kedokteran Universitas Padjadjaran/Rumah Sakit Dr. Hasan Sadikin (RSHS) Bandung selama periode Januari 2014-Desember 2015 menurut catatan medik. Analisis data dilakukan dengan uji Pearson Chi-kuadrat dan juga Mann-Whitney menggunakan Epi-info7. 
Dwi Prasetyo: Perbedaan Manifestasi Klinis dan Laboratorium Kolestasis Intrahepatal dengan Ekstrahepatal pada Bayi

Tabel 1 Karakteristik Subjek

\begin{tabular}{|c|c|c|c|c|}
\hline \multirow[b]{2}{*}{ Variabel } & \multicolumn{2}{|c|}{ Kolestasis } & \multirow[b]{2}{*}{$\begin{array}{l}\text { Total } \\
\mathrm{n}=72\end{array}$} & \multirow[b]{2}{*}{ Nilai p* } \\
\hline & $\begin{array}{c}\text { Intrahepatal } \\
n=61(85 \%)\end{array}$ & $\begin{array}{c}\text { Ekstrahepatal } \\
n=11(15 \%)\end{array}$ & & \\
\hline \multicolumn{5}{|l|}{ Jenis kelamin } \\
\hline Laki-laki & 40 & 3 & $43(60 \%)$ & \multirow{2}{*}{0,017} \\
\hline Perempuan & 21 & 8 & $29(40 \%)$ & \\
\hline \multicolumn{5}{|c|}{ Usia saat datang (bulan) } \\
\hline$\leq 1$ & 15 & 1 & $16(22 \%)$ & \multirow{5}{*}{0,106} \\
\hline 2 & 16 & 0 & $16(22 \%)$ & \\
\hline 3 & 15 & 4 & $19(27 \%)$ & \\
\hline $4-6$ & 11 & 5 & $16(22 \%)$ & \\
\hline$\geq 6$ & 4 & 1 & $5(7 \%)$ & \\
\hline \multicolumn{5}{|c|}{ Lamanya kuning (minggu) } \\
\hline$\leq 1$ & 10 & 1 & $11(15 \%)$ & \multirow{6}{*}{0,079} \\
\hline $2-4$ & 22 & 2 & $24(33 \%)$ & \\
\hline $5-8$ & 13 & 2 & $15(21 \%)$ & \\
\hline $9-12$ & 9 & 1 & $10(14 \%)$ & \\
\hline $13-16$ & 1 & 2 & $3(4 \%)$ & \\
\hline$\geq 16$ & 6 & 3 & $9(13 \%)$ & \\
\hline \multicolumn{5}{|l|}{ Status gizi } \\
\hline Baik & 46 & 7 & $53(75 \%)$ & \multirow{3}{*}{0,650} \\
\hline Kurang & 10 & 3 & $13(18 \%)$ & \\
\hline Buruk & 4 & 1 & $5(7 \%)$ & \\
\hline \multicolumn{5}{|l|}{ Usia kehamilan } \\
\hline Kurang bulan & 8 & 3 & $11(15 \%)$ & \multirow{2}{*}{0,230} \\
\hline Cukup bulan & 53 & 8 & $61(85 \%)$ & \\
\hline \multicolumn{5}{|l|}{ Urin seperti air teh } \\
\hline Ya & 31 & 8 & $39(54 \%)$ & \multirow{2}{*}{0,180} \\
\hline Tidak & 30 & 3 & $33(46 \%)$ & \\
\hline \multicolumn{5}{|l|}{ Feses } \\
\hline Tidak dempul & 19 & 4 & $23(32 \%)$ & \multirow[t]{3}{*}{0,936} \\
\hline Fluktuasi & 11 & 2 & $13(18 \%)$ & \\
\hline Dempul & 31 & 5 & $36(50 \%)$ & \\
\hline
\end{tabular}

Keterangan: *menggunakan uji Pearson Chi-kuadrat; $\mathrm{p}<0,05$ : berbeda bermakna

\section{Hasil}

Selama periode penelitian didapatkan 72 subjek kolestasis pada bayi yang terdiri atas kolestasis IH sebanyak 61 bayi (85\%) dan EH sebanyak 11 bayi $(15 \%)$.

Pada penelitian ini (Tabel 1) didapatkan subjek terbanyak adalah bayi laki-laki $60 \%$. Subjek terbanyak yang datang ke rumah sakit pada usia 3 bulan (27\%), lama kuning 2-4 minggu (33\% bayi), status gizi baik (77\% bayi), usia kehamilan cukup bulan (85\%), urin seperti air teh (54\%), besar hati $<4 \mathrm{~cm}$ sebanyak $61 \%$ dan feses dempul 50\%. Didapatkan perbedaan bermakna antara jenis kelamin pada kolestasis IH dan EH $(p=0,017)$, sedangkan karakteristik lain, yaitu usia datang, lama kuning, status gizi, usia kehamilan, urin seperti air teh, besar hati, dan feses dempul tidak didapatkan perbedaan bermakna.

Terdapat perbedaan yang bermakna pada manifestasi klinis asites antara kolestasis $\mathrm{IH}$ dan EH ( $p=0,047$; Tabel 2). Manifestasi klinis lain seperti venektasi abdomen, hepatomegali, 
Dwi Prasetyo: Perbedaan Manifestasi Klinis dan Laboratorium Kolestasis Intrahepatal dengan Ekstrahepatal pada Bayi

Tabel 2 Perbedaan Manifestasi Klinis antara Kolestasis Intrahepatal dan Ekstrahepatal

\begin{tabular}{|c|c|c|c|c|}
\hline \multirow[b]{2}{*}{ Manifestasi Klinis } & \multicolumn{2}{|c|}{ Kolestasis } & \multirow[b]{2}{*}{$\begin{array}{c}\text { Total } \\
72 \\
\end{array}$} & \multirow[b]{2}{*}{ Nilai p* } \\
\hline & $\begin{array}{l}\text { Intrahepatal } \\
n=61(85 \%)\end{array}$ & $\begin{array}{c}\text { Ekstrahepatal } \\
\text { n=11 (15\%) }\end{array}$ & & \\
\hline \multicolumn{5}{|l|}{ Venektasi abdomen } \\
\hline $\mathrm{Ya}$ & 6 & 1 & $7(10 \%)$ & 0,926 \\
\hline Tidak & 55 & 10 & $65(90 \%)$ & \\
\hline \multicolumn{5}{|l|}{ Hepatomegali } \\
\hline$<4 \mathrm{~cm}$ & 39 & 5 & 44 (61\%) & 0,247 \\
\hline$\geq 4 \mathrm{~cm}$ & 22 & 6 & $28(39 \%)$ & \\
\hline \multicolumn{5}{|l|}{ Splenomegali } \\
\hline Ya & 20 & 3 & $23(32 \%)$ & 0,718 \\
\hline Tidak & 41 & 8 & $49(68 \%)$ & \\
\hline \multicolumn{5}{|l|}{ Asites } \\
\hline Ya & 2 & 2 & $4(6 \%)$ & \\
\hline Tidak & 59 & 9 & $68(95 \%)$ & 0,047 \\
\hline
\end{tabular}

Keterangan: *menggunakan uji Pearson Chi-kuadrat. p<0,05: berbeda bermakna

dan splenomegali tidak didapatkan perbedaan bermakna.

Pada pemeriksaan laboratorium didapatkan distribusi dengan rentang yang berbeda antara kolestasis IH dan EH, tetapi tidak didapatkan perbedaan yang bermakna (Tabel 3).

\section{Pembahasan}

Hasil penelitian ini menunjukkan jenis kelamin terbanyak pada kolestasis adalah laki-laki, keadaan ini sama dengan beberapa penelitian sebelumnya. ${ }^{2,8,11}$ Jenis kelamin perempuan

Tabel 3 Hubungan antara Gambaran Laboratorium pada Kolestasis Intrahepatal dan Ekstrahepatal

\begin{tabular}{|c|c|c|c|c|}
\hline \multirow[b]{2}{*}{ Laboratorium } & \multirow[b]{2}{*}{ Median dan Rentang } & \multicolumn{2}{|c|}{ Kolestasis } & \multirow[b]{2}{*}{ Nilai p* } \\
\hline & & $\begin{array}{c}\text { Intrahepatal } \\
(n=61)\end{array}$ & $\begin{array}{c}\text { Ektrahepatal } \\
(n=11)\end{array}$ & \\
\hline \multirow{3}{*}{$\begin{array}{l}\text { Bilirubin total } \\
\text { (mg/dL) }\end{array}$} & Rata-rata (SD) & 5,95 & 8,981 & \multirow{3}{*}{0,222} \\
\hline & Median & 10,4 & 12,5 & \\
\hline & Rentang & $0,24-24,32$ & $5,43-39,54$ & \\
\hline \multirow{3}{*}{$\begin{array}{l}\text { Bilirubin direk } \\
(\mathrm{mg} / \mathrm{dL})\end{array}$} & Rata-rata (SD) & 4,856 & 7,543 & \multirow{3}{*}{0,205} \\
\hline & Median & 8,27 & 9,79 & \\
\hline & Rentang & $0,37-21,79$ & $3,36-32,22$ & \\
\hline \multirow{3}{*}{ SGOT (U/L) } & Rata-rata (SD) & 118,102 & 215,46 & \multirow{3}{*}{0,266} \\
\hline & Median & 145 & 191 & \\
\hline & Rentang & $28,3-493$ & $80-725$ & \\
\hline \multirow{3}{*}{ SGPT (U/L) } & Rata-rata (SD) & 76,588 & 122,6 & \multirow{3}{*}{0,201} \\
\hline & Median & 82 & 134 & \\
\hline & Rentang & $10-361$ & $49-481$ & \\
\hline \multirow{3}{*}{ ALP (U/L) } & Rerata (SD) & 259,3 & 229,713 & \multirow{3}{*}{0,851} \\
\hline & Median & 429 & 479 & \\
\hline & Rentang & 141-1937 & $272-982$ & \\
\hline \multirow{3}{*}{$\gamma$-GT (U/L) } & Rata-rata (SD) & 251,4 & 445,8 & \multirow{3}{*}{0,159} \\
\hline & Median & 194 & 362 & \\
\hline & Rentang & $44-1409$ & $29-1548$ & \\
\hline
\end{tabular}

Keterangan: *menggunakan uji Mann-Whitney. p<0,05: berbeda bermakna 
pada kolestasis EH pada penelitian ini lebih banyak daripada laki-laki, hasil ini sesuai dengan penelitian yang dilaporkan Young dan Azzam. ${ }^{4}$ Usia subjek saat datang ke rumah sakit terbanyak pada usia $\leq 2$ bulan sebanyak 32 bayi (44\%). Lama keluhan kuning tidak didapatkan perbedaan bermakna antara kolestasis IH dan $\mathrm{EH}$, hal ini memiliki kesamaan dengan penelitian Lee dan Chai. ${ }^{8}$ Status gizi subjek terbanyak adalah gizi baik sebesar 53 bayi (75\%). Usia kehamilan pada penelitian ini menunjukkan tidak memiliki perbedaan bermakna antara kolestasis IH dan EH, sesuai dengan penelitian Omer dkk. ${ }^{2}$ Demikian juga warna urin seperti air teh tidak didapatkan perbedaan antara kolestasis IH dan EH, hasil ini serupa dengan penelitian sebelumnya Young dan Azzam $^{4}$ bahwa warna urin seperti air teh merupakan indikator yang tidak spesifik untuk membedakan antara kolestasis IH dan EH. Pada hasil penelitian pewarnaan feses seperti dempul tidak didapatkan perbedaan bermakna antara kolestasis IH dan EH, keadaan ini berbeda dengan beberapa penelitian sebelumnya bahwa feses dempul dapat digunakan dalam mendiagnosis kolestasis EH. ${ }^{4,8,10,11}$ Manifestasi klinis venektasi abdomen pada penelitian ini didapatkan pada 7 bayi (10\%), splenomegali ditemukan pada 23 bayi (32\%), hasil ini menunjukkan tidak ada perbedaan bermakna, hasil ini sama dengan yang diperoleh beberapa penelitian sebelumnya. Subjek yang mengalami hepatomegali ditemukan sebanyak 28 (39\%) bayi, tidak didapatkan perbedaan yang bermakna antara kolestasis IH dan EH, keadaan ini sama dengan penelitian Urganci dkk., ${ }^{11}$ sedangkan pada penelitian yang dilakukan oleh Lee dan Chai ${ }^{8}$ menunjukkan hasil hepatomegali dengan ukuran $\geq 4 \mathrm{~cm}$ memiliki perbedaan yang bermakna antara kolestasis $\mathrm{IH}$ dan EH. Manifestasi klinis asites pada kolestasis bahwa didapatkan perbedaan yang bermakna $(p=0,047)$ antara IH dan EH, hal ini berbeda dengan penelitian yang dilaporkan Lee dan Chai $(\mathrm{p}=0,72){ }^{8}$

Pemeriksaan laboratorium tersebut untuk dapat menegakkan kolestasis pada penelitian ini seperti bilirubin total tidak didapatkan perbedaan bermakna antara kolestasis IH dan $\mathrm{EH}$, hal ini berbeda dengan yang ditunjukkan pada penelitian Urganci dkk., ${ }^{11}$ namun untuk bilirubin direk memperlihatkan hasil yang sama dengan penelitian Urganci dkk., ${ }^{11}$ yaitu tidak didapatkan perbedaan bermakna. Hasil penelitian ini memperlihatkan bahwa SGPT dan SGOT tidak ada perbedaan bermakna antara kolestasis IH dan EH, sedangkan pada beberapa penelitian sebelumnya dinyatakan bahwa hasil
SGOT dan SGPT merupakan indikator yang sensitif terhadap kerusakan jaringan pada hepar, namun memiliki spesifisitas dan nilai prognosis yang kurang baik. ${ }^{12,13}$ Hasil laboratorium ALP dan $\gamma$-GT serum pada penelitian ini tidak didapatkan perbedaan yang bermakna, sedangkan pada penelitian lain ALP dan $\gamma$-GT serum didapatkan lebih tinggi secara bermakna pada kolestasis EH. ${ }^{13-15}$

Simpulan, didapatkan perbedaan manifestasi klinis asites, sedangkan manifestasi klinis yang lain dan hasil laboratorium tidak didapatkan perbedaan antara kolestasis IH dan EH.

\section{Daftar Pustaka}

1. Gotze $\mathrm{T}$, Blessing $\mathrm{H}$, Grillhosl $\mathrm{C}$, Gerner $P$, Hoerning A. Neonatal cholestasisdifferential diagnoses, current diagnostic procedures, and treatment. Frontier Pediatr. 2015;3(43):1-10.

2. Omer M, Khattak TA, Shah SHA. Etiological spectrum of persistent neonatal jaundice. JMRC. 2010;14(2):87-9.

3. Hoerning A, Raub S, Dechene A, Brosch MN, Kathemann S, Hoyer PF, dkk. Diversity of disorders causing neonatal cholestasis-the experience of a tertiary pediatric center in Germany. Front Pediatr. 2014;2(65):1-8.

4. Young S, Azzam RK. Infantile cholestasis approach and diagnostic algorithm. Dalam: Guandalini S, Dhawan A, Branski D, penyunting. Textbook of pediatric gastroenterology, hepatology and nutrition. Switzerland: Springer Inc; 2016. hlm. 62531.

5. Feldman AG, Sokol RJ. Neonatal cholestasis. Neoreviews. 2013;14(2):1-20.

6. Ruttenstock EZ, Davenport M. Biliary atresia and choledochal malformations. Dalam: Guandalini S, Dhawan A, Branski D, penyunting. Textbook of pediatric gastroenterology, hepatology and nutrition. Switzerland: Springer Inc; 2016. hlm. 63345.

7. Brumbaugh D, Mack C. Conjugated hyperbilirubinemia in children. Ped Rev. 2012;33(7):291-301.

8. Lee WS, Chai PF. Clinical features differentiating biliary atresia from other couse of neonatal cholestasis. Ann Acad Med Singapore. 2010;39(8):648-54.

9. Fischler B, Lamireau T. Cholestasis in the newborn and infant. Clin Res Hepatol Gastroenterol. 2014;38(3):263-7. 
10. Ng VL. Neonatal hepatitis. Dalam: Wyllie RHJ, penyunting. Pediatric gastrointestinal and liver disease. Edisi ke-5. New York: Elsevier; 2006. hlm. 852-81.

11. Urganci N, Cetinkaya F, Kalyoncu D, Cakir EP, Yilmaz B. Infants with cholestasis: diagnosis, management, and outcome. Marmara Med J. 2012;25(1):83-6.

12. Bhatia V, Bavdekar A, Mathai J, Waikar Y, Sibal A. Management of neonatal cholestasis: consensus statement of pediatric gastroenterology chapter of Indian
Academy of Pediatrics. Indian Pediatrics. 2014;51:203-10.

13. Constantin T. Jaundice obstructive syndrome. Curr Health Sci J. 2011;37(2):96-100.

14. Dani C, Pratesi S, Raimondi F, Romagnoli C. Italian guidelines for management and treatment of neonatal cholestasis. Ital J Pediatr. 2015;41(1):69.

15. Brandao MAB, Arnaut LT, Tommaso AMAD, Hessel G. Differential diagnosis of neonatal cholestasis: clinical and laboratory parameters. J Pediatr. 2010;86(1):40-4. 